\title{
SYNTHETIC, SPECTRAL, ANTIMICROBIAL AND QSAR STUDIES ON NOVEL MANNICH BASES OF GLUTARIMIDES
}

\author{
ANJU DAS MANIKPURI ${ }^{a}$ SHEELA JOSHI ${ }^{b}$ AND PADMAKAR V. KHADIKAR*c
}

\author{
${ }^{a}$ Department of chemistry, ISLE,IPS Academy,Knowledge city,Rajendranagar, Indore-452017,MP,India.E.mail:anju.dm@rediffmail.com \\ ${ }^{b}$ School of Chemical Sciences, Devi Ahilya University, Takshashila Campus, Khandwa Road, Indore-452017,MP, India.E.mail: spjoshi11@rediffmail.com \\ cLaxmi fumigation and pest control centre,Research Division,3 Khatipura, Indore-452017, MP,India. E.mail:pvkhadikar@rediffmail.com.
}

(Received: July 28, 2009 - Accepted: July 20, 2010)

\begin{abstract}
A series of forty Mannich bases of glutarimides with sulfonamides and secondary amines were synthesized and evaluated in vitro against six pathogenic Grampositive and Gram-negative bacteria. The synthesized Mannich bases were characterized by elemental and spectral analysis. The modeling anti-bacterial activities of these newly synthesized Mannich bases against six bacteria was attempted employing ${ }^{1} \mathrm{H}$ NMR chemical shift, physicochemical properties and topological indices as the correlating parameters. Our results, based on Quantitative Structure-Activity Relationships (QSARs), have indicated that statistically significant models are obtained for modeling the anti-bacterial activities The results are discussed critically using a variety of statistical parameters.
\end{abstract}

Keywords: Glutarimides, sulfonamides, Mannich bases, antimicrobial activity, QSAR.

\section{INTRODUCTION}

The Quantitative Structure-Activity Relationships (QSARs) are mathematical models relating measured biological activity of series of structurally related compounds / pharmacological agents to the variation in their chemical structure. In cases in which some physico-chemical properties or toxicities of such compounds are related to their structures, the methodology is called Quantitative Structure-Property relationships (QSPRs) or Quantitative Structure-Toxicity Relationships (QSTRs), respectively. Such methodologies are widely used in environmental toxicology to understand the adverse effects of chemical compounds. The QSPR/QSAR/QSTR methodology is very useful for a large number of untested chemicals present in nature, and because of the high costs of biological testing ${ }^{1-19}$. QSAR models are nowadays regarded as a scientifically credible tool for predicting and classifying biological activities of untested chemicals. QSAR has become inexorably embedded as an essential tool in the pharmaceutical industry, from lead discovery, optimization to lead development and computer-aided drug designing ${ }^{20,21}$. A growing trend is to use QSAR early in the drug discovery process as a screening and enrichment tool to estimate from further development those chemicals lacking drug like properties ${ }^{21}$ or those chemicals predicted to elicit a toxic response. The fundamental assumption of QSAR is that variations in the biological activity of a series of chemicals that target a common mechanism of action are correlated with variations in their structural, physical and chemical properties ${ }^{22}$. These biological activity of structurally related chemical compound in terms of in-vivo or in-vitro properties can be determined by experimental or more efficiently by computational mean.. Needless to state that a statistically validated QSAR model is capable of predicting the biological activity of a new chemical within the same series in lieu of the time-consuming and lab our-intensive processes of chemical synthesis and biological evaluation. Applied judiciously, QSAR can save substantial amount of time, money, and human resources.

The molecular structure and NMR chemical shift information of organic compounds acting as drugs can be combined to form powerful models of biological activity. Such data-activity relationship is now-a-day called Quantitative Structure-Data-Activity Relationship (QSDARs) in place of QSAR as it involved the use of spectroscopic data. As is well known ${ }^{23-30}$, chemical shifts in NMR offer a powerful probe for the study of the immediate atomic environment in a molecule. It is worthy to mention that NMR spectra reflect quantum mechanical properties and that QSAR depends on local electrostatics and geometry of the molecule. The ${ }^{13} \mathrm{C}$ NMR spectrum of a compound contains a pattern of frequencies that correspond directly to the quantum mechanical properties of the carbon nuclear magnetic dipole in a magnetic field. The spectral pattern reflects the local electrostatic environment and electron orbital configuration of each atom. The resonance from different carbon orbital configurations is generally well-separated from each other, which permits the use of advantageous for ${ }^{13} \mathrm{C}$ NMR spectral directly to build the QSDAR models ${ }^{23,24}$.

Recently one of the authors (PVK) has initiated interesting investigations on ${ }^{13} \mathrm{C}$ NMR chemical shift ${ }^{25-30}$. His approach was two-fold: firstly to establish
${ }^{13} \mathrm{C}$ NMR chemical shift as a molecular descriptor and secondly to use the same for modeling property-activity- toxicity of organic compounds acting as drugs. One of such applications studied by Khadikar being modeling CA inhibition using ${ }^{13} \mathrm{C}$ NMR chemical shift ${ }^{6}$. Prompted by these results we have undertaken the present study, in that we have investigated variance of antibacterial activity using $\sum$ NMR chemical shifts as one of the correlating parameters. We have also observed that in many cases $\sum$ NMR chemical shifts in combination with physicochemical parameters as well as topological indices improved results are obtained. In doing so we have used maximum $-\mathrm{R}^{2}$ method and applied variety of statistics ${ }^{10}$. We have, therefore, attempted modeling of antibacterial activities of the newly synthesized Mannich bases using $\sum$ NMR chemical shifts, physicochemical parameters as well as topological indices as the correlating parameters. At this stage it is interesting to mention that some people cretised the use of topological indices and consider their use in the development of the models as quite restrictive, since these descriptors only depend on 2D molecular features and not in conformational or electronic properties that are most expected to govern the biological activity of the compounds under study than topological features. Such a criticism is due to the fact that generally no physical significance is attached to topological indices. However, there are several cases in that topological indices correlate excellently with conformational, electronic and other related properties making their judies use in QSAR.

The increasing popularity of the Mannich reaction as well as utility of Mannich bases has been fluted by the ubiquitous nature of nitrogen in drugs and natural products as well as by the potential of this multi-component reaction to generate diversity. Interest in Mannich bases has been quite attractive and wide ranged considering the enormous domain of the applications involving variant biological ${ }^{31-35}$, pharmaceutical ${ }^{36-40}$ and industrial ${ }^{41-43}$ properties. Glutarimides moiety with the intact imide group is acting as the carrier molecule (vector), which transports biologically active substitutents (functional groups) through cell membranes ${ }^{44}$. It is also a component of newly synthesized antibiotics, which exert antiviral and antifungal activity ${ }^{45}, 46$. Glutarimides (2,6-piperidinedione) moiety is found in a number of antibiotics with antiviral and fungicidal activity ${ }^{47-50}$. Furthermore, the 2,6-piperidinedione moieties constitute an important centre in several new anticancer drugs which have recently been introduced into experimental chemotherapy ${ }^{51-53}$. It is also a structural part of a number of molecules with interesting biochemical activity ${ }^{54}$. In view this we have attempted aminoalkyaltion of various glutarimides-moieties with sulphonamides and secondary amines. The structural characterization these newly synthesized Mannich bases is made using elemental, UV, IR and ${ }^{1} \mathrm{H}$ NMR studies.

The anti-bacterial potential vis-à-vis QSAR study of the newly synthesized Mannich bases in the present is made in the following four different ways:

(i ) QSAR study based on using $\sum$ NMR chemical shifts as molecular descriptor;

(ii) QSAR study based on using physicochemical parameters as molecular descriptor;

(iii) QSAR study based on using topological indices as molecular 
descriptor, and (iv) QSAR study based on combination of $\sum$ NMR chemical shifts, with physicochemical properties and or topological indices.

The results obtained are presented in Tables 1-7.

\section{EXPERIMENTAL SECTION}

\section{General information.}

All the m.p. of the synthesized Mannich bases ware determined using Thomas Hoover capillary melting point apparatus and their purity was ascertained by TLC method. The antimicrobial screening was performed using paper disc method and the results were statistically evaluated using variety of statistical parameters. Mullar Hinton Agar was taken as media for cultivation of bacteria. The inhibitory effect of the samples were measured against each of the bacteria after incubation for 24 hours at $37^{\circ} \mathrm{C}$. The experiments were run in triplicate and the mean of readings were recorded.

\section{Synthesis of Mannich bases from primary amines.}

Mannich bases of glutarimides were prepared by reacting various glutarimides $(0.01 \mathrm{~mol})$ dissolved in $20 \mathrm{~mL}$ of ethanol with sulfonamide $(0.01 \mathrm{~mol}) .2 .5 \mathrm{~mL}(0.01 \mathrm{~mol})$ of formaldehyde solution $(37 \%, \mathrm{v} / \mathrm{v})$ was added slowly with constant stirring. The $\mathrm{pH}$ of the mixture was adjusted to 3.5 by adding $0.5 \mathrm{~mL}$ of $1 \mathrm{~mol} \mathrm{~L}^{-1} \mathrm{HCl}$. The mixture was kept at efficient ice cooling for half an hour, and then refluxed on water bath. Reflux time varied with the sulfonamide used. The refluxed mixture was kept at $0^{\circ} \mathrm{C}$ for four days when crystalline product was obtained. The product was re-crystallized from dry distilled ethanol and dioxane-water (1:1). The compounds were characterized by elemental, UV, IR and NMR studies.

Synthesis of Mannich bases from secondary amines.

Secondary amine $(0.01 \mathrm{~mol})$ was added to an ethanolic solution $(50 \mathrm{~mL})$ of glutarimides $(0.01 \mathrm{~mol})$ in a flat bottom flask. Amount of $0.4 \mathrm{~mL}(0.015 \mathrm{~mol})$ of formaldehyde solution $(37 \%, v / v)$ was added slowly with constant stirring. The reaction mixture was stirred at $70-75^{\circ} \mathrm{C}$ for 3.0 to 8.5 hours, depending upon the secondary amine. The remaining portion of formaldehyde solution was added in two installments after 1 and 2 hours, respectively. The reaction mixture was kept overnight in the refrigerator. Next day, the excess of solvent was distilled off from the reaction mixture under reduced pressure. It was again kept for crystallization in the refrigerator. The products obtained were purified by recrystallization from dry distilled ethanol. The compounds were characterized by elemental, UV, IR and NMR studies. For details see schemes $\mathbf{1}$ and 2.

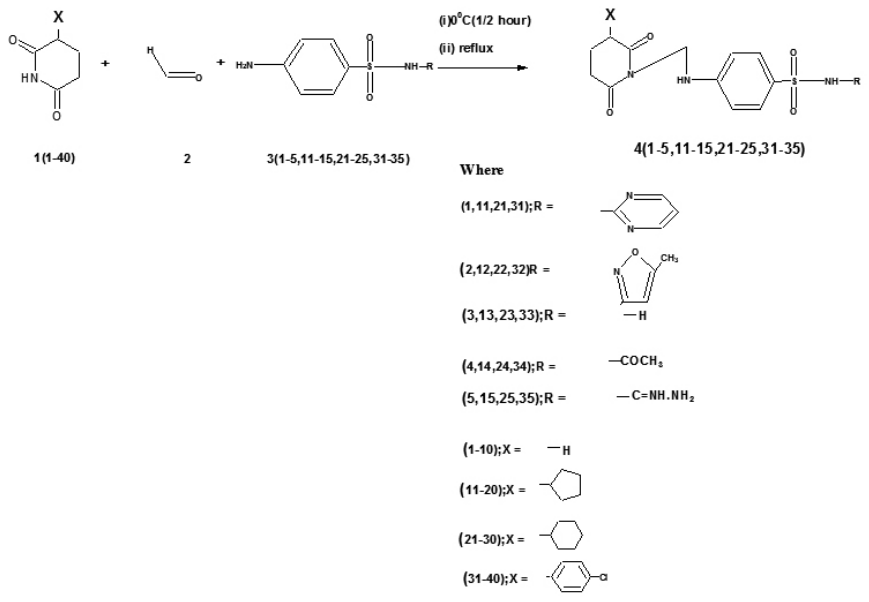

Scheme 1: Synthesis of Mannich bases from sulphonamides.

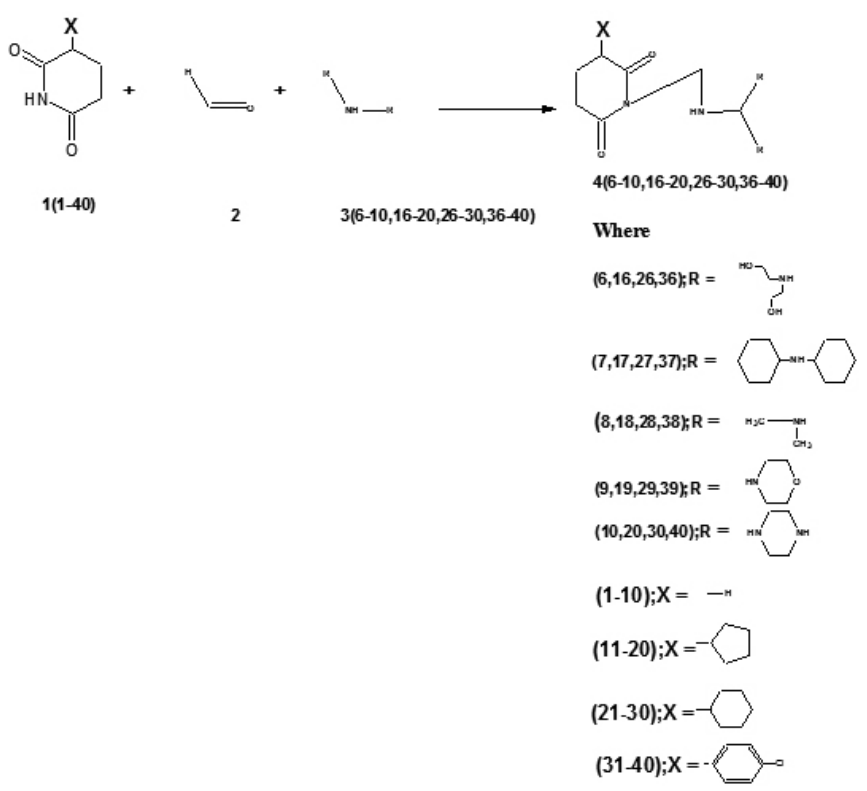

Scheme 2: Synthesis of Mannich bases from secondary amines.

\section{Spectral studies.}

The ${ }^{1} \mathrm{H}$ NMR spectra in DMSO and $\mathrm{CDCl}_{3}$ solvent were recorded on Bruker DRX-300 FT NMR Spectrometer. The UV spectra were recorded on Schimadzu UV-160A, UV-visible spectrophotometer.

\section{Antimicrobial activity .}

The sum of the NMR chemical shift, $\sum$ NMR, and the anti-bacterial activity for the set of 40 Mannich bases as given in Table 1.The useful descriptors ( $\sum$ NMR, physical parameters and topological indices) from a large set were chosen using multiple variable selection and are given in Table 2 . The regression analyses were performed starting from a single to ten descriptors and the regression reports are given as supplementary material. The plots of number of descriptors against $\mathrm{R}^{2}$ (Fig. 1) indicated that eight variable model is the most appropriate model for modeling anti-bacterial activity against all the six bacteria.. This is in accordance with the rule of Thumb ${ }^{63}$ which states that the descriptors to be used in multiple regression analysis should be one-fifth of the total number of compounds under study. The detail regression analysis of the models is given in the text under Results and Discussion section. The correlelation matrices for the parameters involved in these models are also presented separately as supplementary material. Finally, Ridge parameters for each of these models are also mention as supplementary material.

Table 1. Antibacterial activity of the Mannich bases and their and NMRChemical shift (1-40).

\begin{tabular}{|c|c|c|c|c|c|c|c|}
\hline C.N. & ENMR & $\begin{array}{c}\text { B. } \\
\text { subtilis }\end{array}$ & S. typhi & E.coli & $\begin{array}{c}\text { S. } \\
\text { aureus }\end{array}$ & $\begin{array}{c}\text { K. pneu- } \\
\text { moniae }\end{array}$ & $\begin{array}{c}\text { P. auru- } \\
\text { ginosa }\end{array}$ \\
\hline 1 & 33.98 & 10.5 & 10.5 & 10.0 & 11.5 & 10.8 & 10.5 \\
\hline 2 & 34.26 & 10.0 & 12.0 & 12.0 & 11.0 & 11.5 & 10.0 \\
\hline 3 & 31.68 & 10.5 & 10.0 & 11.0 & 12.0 & 12.0 & 10.5 \\
\hline 4 & 32.5 & 11.0 & $10 ; .0$ & 8.5 & 9.5 & 13.0 & 11.0 \\
\hline 5 & 34.29 & 12.0 & 11.0 & 7.5 & 10.5 & 13.5 & 12.0 \\
\hline 6 & 30.42 & 13.0 & 11.5 & 10.0 & 10.0 & 14.2 & 13.0 \\
\hline 7 & 36.44 & 11.0 & 10.5 & 10.5 & 10.5 & 15.8 & 11.0 \\
\hline 8 & 34.36 & 10.5 & 8.5 & 11.0 & 10.5 & 10.8 & 10.5 \\
\hline 9 & 30.88 & 10.0 & 10.0 & 11.5 & 10.0 & 10.2 & 10.0 \\
\hline 10 & 32.48 & 11.2 & 11.0 & 11.5 & 11.5 & 11.8 & 11.2 \\
\hline 11 & 30.98 & 11.6 & 11.0 & 11.0 & 12.4 & 13.0 & 11.6 \\
\hline 12 & 31.28 & 11.8 & 11.0 & 10.0 & 11.0 & 13.5 & 11.8 \\
\hline 13 & 36.92 & 13.2 & 11.5 & 10.5 & 11.2 & 12.5 & 13.2 \\
\hline 14 & 32.22 & 14.8 & 12.5 & 12.0 & 11.5 & 12.0 & 14.8 \\
\hline
\end{tabular}




\begin{tabular}{|c|c|c|c|c|c|c|c|}
\hline 15 & 30.24 & 15.6 & 13.5 & 12.5 & 12.0 & 12.0 & 15.6 \\
\hline 16 & 34.60 & 10.5 & 10.0 & 10.5 & 11.0 & 11.5 & 10.5 \\
\hline 17 & 34.28 & 8.5 & 10.0 & 10.5 & 11.0 & 11.5 & 8.5 \\
\hline 18 & 32.60 & 7.5 & 10.0 & 10.5 & 10.5 & 11.6 & 7.5 \\
\hline 19 & 34.46 & 10.5 & 10.0 & 10.0 & 11.0 & 11.5 & 10.5 \\
\hline 20 & 30.92 & 12.0 & 10.0 & 11.0 & 11.5 & 11.5 & 12.0 \\
\hline 21 & 30.28 & 13.4 & 11.5 & 11.0 & 11.5 & 11.5 & 13.4 \\
\hline 22 & 30.60 & 11.0 & 12.5 & 11.5 & 12.0 & 12.0 & 11.0 \\
\hline 23 & 32.42 & 15.5 & 13.5 & 12.5 & 12.5 & 11.5 & 15.5 \\
\hline 24 & 32.72 & 14.8 & 12.5 & 11.5 & 11.0 & 11.0 & 14.8 \\
\hline 25 & 27.04 & - & - & - & - & - & - \\
\hline 26 & 34.42 & 12.0 & 13.5 & 12.5 & 12.0 & 12.5 & 12.0 \\
\hline 27 & 30.90 & 12.5 & 12.5 & 10.0 & 12.5 & 12.0 & 12.5 \\
\hline 28 & 34.90 & 11.5 & 10.5 & 11.0 & 12.5 & 12.5 & 11.5 \\
\hline 29 & 32.48 & 11.0 & 10.5 & 10.5 & 11.5 & 12.5 & 11.0 \\
\hline 30 & 36.5 & 10.0 & 10.0 & 10.5 & 14.5 & 12.5 & 10.0 \\
\hline 31 & 30.26 & 10.8 & 10.8 & 12.2 & 13.5 & 11.5 & 10.5 \\
\hline 32 & 34.62 & 10.4 & 13.8 & 11.2 & 12.5 & 10.5 & 15.5 \\
\hline 33 & 34.42 & 10.6 & 11.8 & 13.2 & 16.5 & 12.0 & 12.5 \\
\hline 34 & 30.24 & 10.8 & 12.8 & 12.2 & 17.5 & 12.5 & 11.5 \\
\hline 35 & 32.4 & 10.9 & 13.8 & 13.2 & 12.5 & 12.5 & 11.5 \\
\hline 36 & 30.92 & 10.6 & 11.8 & 14.2 & 11.5 & 11.5 & 11.5 \\
\hline 37 & 30.24 & 10.4 & 14.8 & 15.2 & 10.5 & 10.5 & 11.5 \\
\hline 38 & 30.2 & 10.4 & 13.8 & 11.2 & 13.5 & 13.0 & 11.5 \\
\hline 39 & 34.92 & 10.0 & 12.8 & 10.2 & 12.5 & 13.5 & 11.5 \\
\hline 40 & 34.9 & 10.0 & 11.8 & 12.2 & 13.5 & 11.5 & 11.5 \\
\hline
\end{tabular}

Codes for the bacteria

\begin{tabular}{ll}
\hline Code & Bacteria \\
\hline C32 & B.subtilis \\
C33 & S.typhi \\
C34 & E.coli \\
C35 & S.aureus \\
C36 & K.pneumoniae \\
C37 & P.aeruginosa \\
\hline
\end{tabular}

\section{B.subtilis}

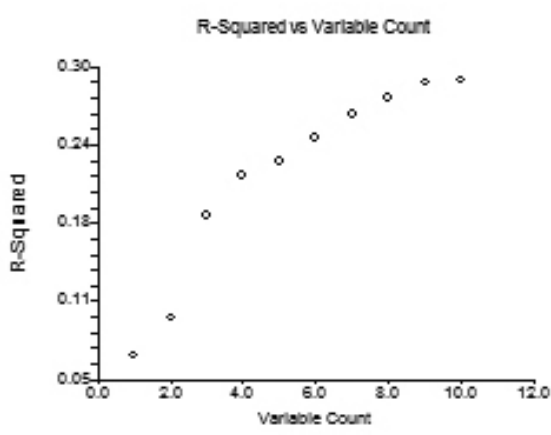

\section{S.typhi}

Table 2. Useful variables from the larger pool and their codes.

\begin{tabular}{llll}
\hline Code & Variable & Symbol & Name of the variable \\
\hline A & C2 & SNMR & Sum of NMR \\
B & C9 & d & Density \\
C & C10 & $\alpha$ & Polarizability \\
D & C11 & MM & Monoisotopic Mass \\
E & C12 & NM & Nominal Mass \\
F & C13 & AM & Average Mass \\
G & C14 & ZM1 & First Zagreb index M1 \\
H & C15 & ZM2 & Second Zagreb index M2 \\
I & C16 & Pol & Polarity number \\
J & C17 & SMT1 & Schultz Molecular Topological Index \\
K & C18 & Xu & Xu Index \\
L & C19 & SP1 & Superpendentic Index \\
M & C20 & W & Wiener Index \\
N & C21 & Har & Harary Index \\
O & C22 & ${ }^{0} \mathrm{c}$ & Zero order randic connectivity Index \\
P & C23 & ${ }^{1} \mathrm{c}$ & First order randic connectivity Index \\
Q & C24 & ${ }^{2} \mathrm{c}$ & Second order randic connectivity Index \\
R & C25 & ${ }^{3} \mathrm{c}$ & Third order randic connectivity Index \\
S & C26 & ${ }^{4} \mathrm{c}$ & Fourth order randic connectivity Index \\
T & C27 & ${ }^{0} \mathrm{c}^{v}$ & Zero order randic valence connectivity \\
U & C28 & ${ }^{1} \mathrm{c}^{v}$ & Index \\
& & & First order randic valence connectivity \\
V & $\mathrm{C} 29$ & ${ }^{2} \mathrm{c}^{v}$ & Index \\
& & & Second order randic valence connectivity \\
W & $\mathrm{C} 30$ & ${ }^{3} \mathrm{c}^{v}$ & Index \\
& & & Third order randic valence connectivity \\
X & $\mathrm{C} 31$ & ${ }^{4} \mathrm{c}^{v}$ & Index \\
& & & Fourth order randic valence connectivity \\
& & & Index \\
\hline
\end{tabular}
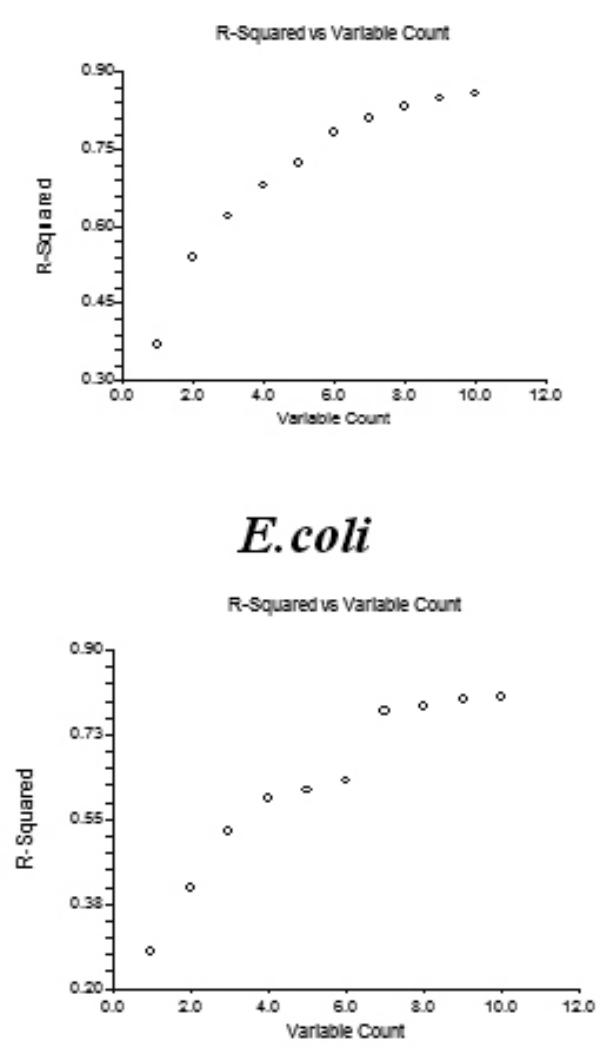


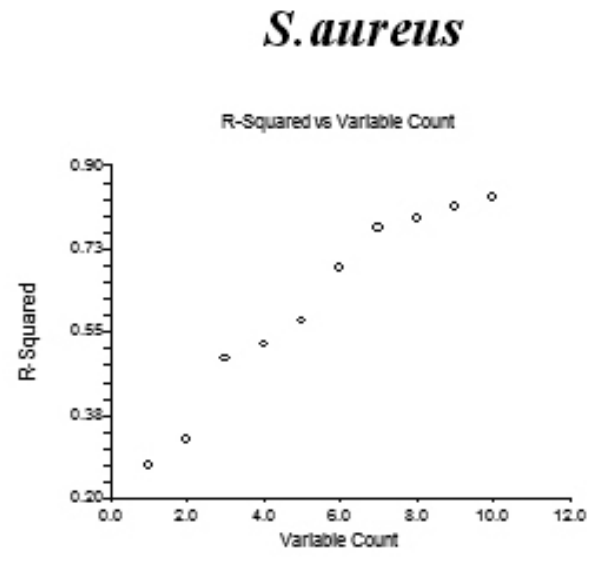

\section{K.pneumoniae}

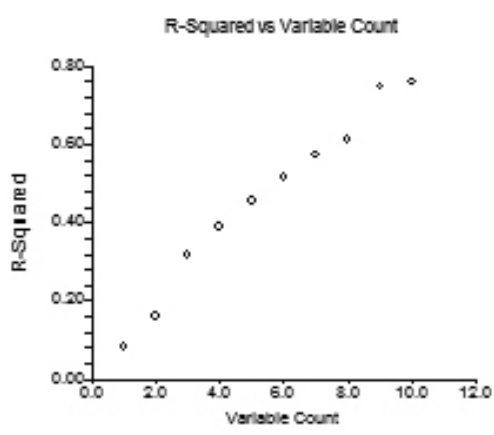

\section{P.aeruginosa}

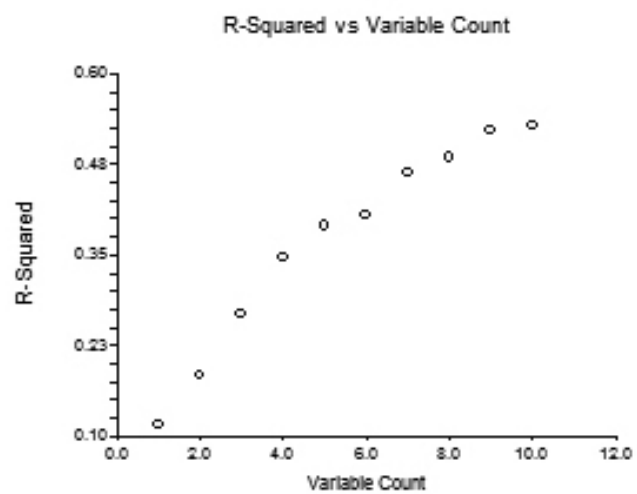

Figure 1. Correlation of number of descriptors (variable count) with $\mathrm{R}^{2}$ Supplementary material. (1) Variable selection for multiple regression analysis.

\section{RESULTS AND DISCUSSION}

A perusal of the Table 1 demonstrates the sequence of activity in each of the bacteria used in the present study. The data presented in this Table 1 show that degeneracy in activity exists in each of the six bacteria used. Also that the sequences of activities are very different for the bacteria used. This data, therefore, do not exhibit any structure-activity relationship for the variation of antibacterial activity. This has prompted us to compute molecular descriptors and then to examine structure activity using QSAR methodology.

Preliminary regression analysis has indicated that use of $\sum$ NMR chemical shifts alone do not give any statistically significant model. However, when $\sum$ NMR chemical shifts are combined with physical properties and also topological indices better quality models are obtained and that most appropriate models are obtained when all the three types of molecular descriptors are used together. We observed that if $\sum$ NMR chemical shifts are eliminated from the most appropriate model the quality of the model is decreased significantly. This exhibits the dominating role of $\sum$ NMR chemical shifts. The proposed models are given below:

\section{(i) Model for B.subtilis} $\mathrm{C} 2$

Anti-bacterial activity $($ B.subtilis $)=6.7268+4.6812^{*} 10^{-2}\left( \pm 3.6965^{*} 10^{-2}\right)$

$$
\begin{aligned}
& +7.0545 * 10^{-3}\left( \pm 1.6369^{*} 10^{-2}\right\} \mathrm{C} 3 \\
& -3.0702 * 10^{-3}\left( \pm 2.107 * 10^{-3}\right) \mathrm{C} 17 \\
& +0.01124\left( \pm 8.949774^{*} 10^{-3}\right) \mathrm{C} 20 \\
& +0.24859( \pm 0.3089584) \mathrm{C} 24 \\
& -6.4740^{*} 10^{-2}( \pm 0.1287502) \mathrm{C} 27 \\
& +1.1076^{*} 10^{-4}\left( \pm 1.4978^{*} 10^{-4}\right) \mathrm{C} 28 \\
& +0.33949( \pm 0.2729939) \mathrm{C} 30
\end{aligned}
$$

$\mathrm{N}=40, \mathrm{CV}=0.1080532, \mathrm{R}^{2}=0.2601, \mathrm{R}^{2} \mathrm{~A}=0.0000, \mathrm{~F}=0.7470$

(ii) Model for S.typhi

Anti-bacterialactivity $($ S.typhi $)=9.888266-4.510451 * 10-2( \pm 2.321028 * 10$ 2) $\mathrm{C} 2$

$+1.473106( \pm 0.2763391) \mathrm{C} 16$

$-1.525129( \pm 0.4197105) \mathrm{C} 21$

$+0.2966534( \pm 0.2012577) \mathrm{C} 24$

$+2.086771( \pm 1.280614) \mathrm{C} 25$

$-0.3372007( \pm 0.1177242) \mathrm{C} 26$

$-0.2197946( \pm 6.764524 * 10-2) \mathrm{C} 27$

$+2.066341 * 10-4( \pm 9.204068 * 10-5) \mathrm{C} 28$

$\mathrm{N}=40, \mathrm{CV}=6.8970, \mathrm{R}^{2}=0.8328, \mathrm{R}^{2} \mathrm{~A}=0.7541, \mathrm{~F}=10.5844$

(iii) Model for E.Coli

Anti-bacterial activity $($ E.coli $)=17.3471-8.5342 * 10^{-2}\left( \pm 3.2712 * 10^{-2}\right) \mathrm{C} 2$

$-8.2224( \pm 4.0231 \mathrm{C} 9$

$+12.3122( \pm 8.025793) \mathrm{C} 11$

$+12.1831( \pm 8.015417) \mathrm{C} 12$

$-4.3494 * 10^{-2}\left( \pm 4.455554 * 10^{-2}\right) \mathrm{C} 15$

$-1.3177( \pm 0.5166374) \mathrm{C} 18$

$+2.6913 * 10^{-4}\left( \pm 1.0817 * 10^{-4}\right) \mathrm{C} 28$

$-0.3951( \pm 0.1142) \mathrm{C} 29$

$\mathrm{N}=40, \mathrm{CV}=7.9712, \mathrm{R}^{2}=0.7836, \mathrm{R}^{2} \mathrm{~A}=0.6817, \mathrm{~F}=7.6935$

(iv) Model for S.aureus

Anti-bacterialactivity $($ S.aureus $)=32.7323+0.1425\left( \pm 3.5039 * 10^{-2}\right) \mathrm{C} 2$

$+1.8960( \pm 0.2853) \mathrm{C} 16$

$-1.0472 * 10^{-2}\left( \pm 2.1726^{*} 10^{-3}\right) \mathrm{C} 17$

$+4.9660 * 10^{-2}\left( \pm 9.5501 * 10^{-3}\right) \mathrm{C} 20$

$-5.5463( \pm 0.8328) \mathrm{C} 22$

$-0.3017( \pm 0.2427) \mathrm{C} 24$

$-3.7687 * 10^{-4}\left( \pm 1.1822 * 10^{-4}\right) \mathrm{C} 28$

$-0.5538( \pm 0.1980) \mathrm{C} 31$

$\mathrm{N}=40, \mathrm{CV}=7.7740, \mathrm{R}^{2}=0.7898, \mathrm{R}^{2} \mathrm{~A}=0.6909, \mathrm{~F}=7.9863$

(v) Model for K.pneumoniae

Anti-bacterialactivity $($ K.pneumoniae $)=6.3773+0.7490( \pm 0.2062) \mathrm{C} 2$

$-15.4731( \pm 7.2948) \mathrm{C} 10$

$+15.4189( \pm 7.2829) \mathrm{C} 11$

$-5.4125^{*} 10^{-3}\left( \pm 1.9237^{*} 10^{-3}\right) \mathrm{C} 12$

$+2.0276 * 10^{-2}\left( \pm 8.3083 * 10^{-3}\right) \mathrm{C} 17$

$+0.3188( \pm 0.2348) \mathrm{C} 20$

$-3.1490 * 10^{-4}\left( \pm 1.1616^{*} 10^{-4}\right) \mathrm{C} 28$

$\mathrm{N}=40, \mathrm{CV}=7.1296, \mathrm{R}^{2}=0.6142, \mathrm{R}^{2} \mathrm{~A}=0.4326, \mathrm{~F}=3.3825$

(vi) Model for P.aeruginosa

Anti-bacterialactivity $($ P.aeruginosa $)=6.8045+10.9606( \pm 0.3556) \mathrm{C} 16$

$+1.0584( \pm 0.4314) \mathrm{C} 18$

$-1.9102( \pm 0.6176) \mathrm{C} 21$

$+3.8562( \pm 1.7120) \mathrm{C} 25$

$-0.6298( \pm 0.3388) \mathrm{C} 26$

$-0.1285( \pm 0.1361) \mathrm{C} 27$

$+2.0391 * 10^{-4}\left( \pm 1.3594 * 10^{-4}\right) \mathrm{C} 28$

$+0.6882( \pm 0.4046) \mathrm{C} 31$

$\mathrm{N}=40, \mathrm{CV}=9.0854 * 10^{-2}, \mathrm{R}^{2}=0.4846, \mathrm{R}^{2} \mathrm{~A}=0.2420, \mathrm{~F}=1.9978$ 


\section{Physicochemical significances of the proposed models}

It will be interesting to discuss the physicochemical significances of the proposed models. We observed that invariably all the models contain $\mathrm{C} 2$ $\left(\sum N M R\right)$ as the correlating parameter. It means, therefore, that $\sum$ NMR play a dominating role in modeling antibacterial activity against all the bacteria. That is electronic effect is the main parameter for the exhibition of the activity.

In case of models -3 and model-5, in addition to $\sum$ NMR, physicochemical parameters along with topological indices are involved in modeling the antibacterial activities. The physicochemical parameters involved indicate that the size and shape are responsible for the exhibition o the antibacterial activities against these bacteria. The topological indices involved in these and other models are mainly connectivity indices. This means that the extent of connectivity is the responsible for the exhibition of anti bacterial activity against all the bacteria used.

It is also worth mentioning that all the proposed models, except model-5 (which has 7 correlating parameters), all other models contain 8 correlating parameters. Looking to the size of the sample i.e. the number of compounds used this is accordance with the rule of thumb. Furthermore, the plot of number of variables used against $\mathrm{R} 2$

( Fig.1) also favors the use of 7 to 8 correlating parameters.

The aforementioned models were further examined employing Ridge statistics.

\section{Ridge statistics.}

Application of Ridge statistics provides important statistical parameters namely variance inflation factors $(V I F \mathrm{~s})$ for each of the parameters involved in the model. The VIF is defined for each variable in the equation, and not for the equation as a whole, so there should be as many $V I F$ s, as there are correlating parameters. The VIF is defined as:

$$
V I F=1\left(1-R^{2}\right)
$$

Where $R_{\mathrm{i}}$ is the multiple correlation coefficient of the $\mathrm{i}^{\text {th }}$ independent variable on all of the other independent variables. In the proposed models, all these VIFs should be less than 10 indicating that no co- linearity problem exists in the model.

The VIFs values for the parameters involved in the aforementioned models are given supplementary material; which shows that each of the models contain one or more descriptors having VIFs values larger than 10 . Therefore, based on $V I F \mathrm{~s}$ values a major problem of co- linearity exists for them. However, the magnitude of condition number indicates the existing of mild co- linearity. In such cases Randic recommendations ${ }^{59-60}$ are used to arrive at the final decision.

\section{Randic recommendations}

Randic ${ }^{59-60}$ stated that if a descriptor strongly correlates with another descriptor already used in a regression, such a descriptor in most studies should be discarded. For example ${ }^{I} \chi$ and ${ }^{2} \chi,{ }^{l} \chi$ often strongly correlate and in many structure-property-activity studies ${ }^{2} \chi$ has been discarded. This is not theoretically justified and despite the widespread practice should be stopped. Although two highly correlated descriptors overall depict the same features of molecular structure, it is important to recognize that even highly interrelated descriptors differ in some other structural traits. The difference between them may be relatively small but nevertheless very important for structure-property regression.

The criteria for inclusion or exclusion of descriptors should not be based on parallelism between descriptors even if overwhelming, but should be based on whether the part in which two descriptors disagree is or is not relevant for the characterization of the property considered .If the part in which the second descriptor differ from the first, regardless of how small it is, is relevant for the property under consideration, then the descriptor should be included. Randic ${ }^{59}$, ${ }^{60}$ further stated that the selection of descriptors to be used in structure-propertyactivity studies should not be delegated solely to computers, although statistical criteria will continue to be useful for preliminary screening of descriptors taken from a large pool. Often in an automated selection of descriptors, a descriptor will be discarded because it is highly correlated with another descriptor already selected. But what is important is not whether two descriptors parallel one another; i. e. duplicates much of the same structural information, but whether they are complementary in those parts that are important for structure-propertyactivity correlations. Hence, the residual of the correlation between two descriptors should be examined and kept or discarded depending on how well it can improve the correlation based on already selected descriptors.

\section{CONCLUSIONS}

The newly synthesized Mannich bases appeared to be very potent and outstanding antibacterial agents with promising activity and found safer. These novel Mannich bases could be used as useful drug. Our findings will prove helpful to those who are engrossed in the synthesis of potential Mannich bases as drugs with minimum side effects and also having comparatively low cost. Thus, the result presented in this paper is valuable in constructing pharmacologically imperative heterocyclic as new exotic drugs. Efforts are continuing to synthesize new amino-methyl derivatives of various active hydrogen compounds, that the derived compounds may have enhanced pharmacological activity. Our results also show that the antibacterial activity of the Mannich bases could be modeled using sum of the NMR chemical shifts, physicochemical parameters, and topological indices. The combination of these parameters gives statistically significant models for modeling antibacterial activity against S.typhi, E.coli, S.aureus, and K.pneumoniae.

\section{ACKNOWLEDGEMENTS}

The authors wish to express gratitude to the Director, CDRI, Lucknow, India for recording elemental analysis.

\section{REFERENCES}

1. C. Hansch, A. Leo, In Exploring QSAR: Fundamental and application in chemistry and biology ,S.R. Heller, Ed. American Chemical Society: Washington, DC. (1995)

2. M. Karelson, Molecular descriptors in $Q S A R / Q S P R$, Wiely-Interscience (2000)

3. M.V. Diudea, M.S. Florescn, P.V. Khadikar, Molecular topology and its applications, EFICON Press: Bucarest. (2006)

4. C. Hansch, B.R. Telzer, L. Zhang, Crit. Rev. Toxicol. 25,67- 89. (1995)

5. H. Branes, Mamalian toxicology-property prediction and QSAR technique,Peter Fisk Associates Whitestable: Kent. (2004)

6. S. Bradbury, Taxicol. Lett. 79,229-237, (1995)

7. P.R. Duchowicz, E.A. Castro, A.A. Toropov, E. Benfenati, Top Heterocycl. Chem 3, 1-18, (2006)

8. M.V. Diudea, (Ed) QSPR/QSAR Studies by Molecular Descriptors, Nova Science, (2000)

9. J. Devillers, A.T. Balaban, (Eds) Topological Indices and Related Descriptors in QSAR and QSPR, Gordon \& Breach Science Pub., Amsterdam (The Netherlands), (1999)

10. M.V. Diudea, (Ed) QSPR/QSAR Studies by Molecular Descriptors, Nova Science( 2000 )

11. D. Janezic, Nikolic, T.N.Sonja, Graph theoretical matrices in chemistry, University of Kragujevac, Faculty of Science, Kragujevac, 205 ( 2007)

12. Li, Xueliang, Tianjin, I.Gutman, Mathematical Aspects of RandicType Molecular Structure Descriptors Nankai University, University of Kragujevac, Kragujevac, Serbia University of Kragujevac Faculty of Science, Kragujevac ISBN: 86-81829-67-X, 330 ,(2006) Rouvray, H. Dennis (Editor), Complexity: Introduction and Fundamentals University of Georgia, Athens, Georgia, USADanail Bonchev (Editor), Virginia Commonwealth Univ., ichmond, USACRC PressISBN: 0-41528791-X, 208, (2003)

13. R. King, Bruce (Editor), Topology in Chemistry: Discrete Mathematics of Molecules University of Georgia, Athens, Georgia, USADennis H. Rouvray (Editor), University of Georgia, Athens, Georgia, USAALBION/ HORWOOD Pub.ISBN: 1898563764, 400 ,( 2002)

14. H.Diudea, V Mircea., I.Gutman, Molecular Topology NOVA SCIENCEISBN, 332 , (2001)

15. R. Todeschini, Handbook of Molecular Descriptors WILEY-VCHISBN, 668, (2000)

16. L.Kier, R.Hall, Molecular Structure description ACADEMIC PRESS ISBN,286, (1999)

17. A.T.Balaban, (Editor), From Chemical Topology to Three-Dimensional Geometry PLENUM PRESSISBN, 420 ,(1997)

18. G.P.Mezey, Shape in Chemistry: An Introduction to Molecular Shape and Topology JOHN WILEY \& SONS, $224,(1993)$

19. N.Trinajstic, Chemical Graph Theory CRC Press, 322 ,( 1992)

20. H.D.Rouvray, (Editor), Chemical Graph Theory: Introduction and Fundamentals USATAYLOR \& FRANCIS, 300 ,(1991)

21. R.B.King, (Editor), Graph Theory and Topology in Chemistry, USA ELSEVIER, 575 ,(1987) 
22. D. Bonchev, Information Theoretic Indices for Characterization of Chemical Structures USARESEARCH STUDIES PRESS, 249, 1983

23. A.T. Balaban, (Editor), Chemical Applications of Graph Theory ACADEMIC PRESS, 389 , ( 1976)

24. P.V.Khadikar, S.Singh, M. Jaiswal, D. Mandoli, Bioorg. Med. Chem. Lett, 14, 4795,(2004).

25. P.V. Khadikar, N.S. Sapare, S.Kumar, R.N. Patel, Indian J.Chem.. 39A, 386(2000).

26. M. Jaiswal, P. V. Khadikar, J. Indian Chem. Soc., 82, 247-249(2005).

27. Patel, R.N. Kumar,S. Pande, K.B. Khadikar,P.V. Spectro.Chem.Acta. 58A, 2961,(2001).

28. S.N.Kane, A.K. Sharma, A. Gupta, P.V.Khadikar, S.M.Ali, Bull.Soc. Chem.Belg. 105,155(1996).

29. S. Joshi, A .D .Manikpuri, D. Khare, J. Indian Chem.Soc. 85, 508-512, (2008) .

30. S. Joshi, A. D. Manikpuri, P. Tiwari, Bioorganic \& Medicinal Chemistry Letters 17, 645-648, (2007).

31. S Joshi, N. Khosla, D. Khare, R. Sharda, Bioorganic \& Medicinal Chemistry Letters 15, 221-226, (2005).

32. S. Joshi, P.Tiwari, N. Khosla, Bioorganic \& Medicinal Chemistry 12, $571,(2004)$.

33. S. Joshi, N. Khosla,D.Khare, Bioorganic \& Medicinal Chemistry Letters 13, 3747, (2003).

34. D. Sriram, P.Yogeeswari, S.P.Reddy, Bioorg.Med.Chem.Lett.16, $2113-$ 2116,(2006)

35. M. Tramontiny, L. Angiolini, Mannich bases: Chemistry and uses, CRC Press, Boca Raton, (1994)

36. A. B. McKaguue, J.Appl. Chem.Biotechnol. 24, 607, (1974).

37. M. Park, J.Lee, J. Choi ,Bioorganic \& Medicinal Chemistry Letters 6, 1297-1302 (1996) .

38. D.Michalska, B.Morzyk, D.C.Bieńko, W.Wojciechowski. Med Hypotheses. 54 472-4, (2000) .

39. T.Otani, Y.Minami, H.Yoshida, H.Nishida, T.Nakayama, K. Ohishi, H.Tsuda, I. Ikeda, J. Jpn.Soc. Cancer Ther. 23, 1560 (1988).

40. T. Sonoda, M. Kobayashi, M. Ubukata, H. Osada, K. Isono, J. Antibiot. 45, 1963, (1992).

41. T. Otani, Y. Minami, H. Matsumoto, T. Marunaka, Z.-X. Lou and Q.-W. Yu, J. Antibiot. 42, 654, (1989).

42. K. Sugawara, Y. Nishiyama, S. Toda, N. Komiyama, M. Hatori, T. Monyama, Y. Sawada, H. Kamei, M. Konishi and T. Oki, J. Antibiot, 45 , 1433, (1992).

43. T. Sonoda, H. Osada, J. Uzawa and K. Isono, J. Antibiot. 44, 160, (1991).

44. T. Sonoda, K. Kobayashi, M. Ubukata, H. Osada and K. Isono, $J$. Antibiot., 45, 1963,(1992).

45. S.R. Burzynski ,T.T. Hai, Drugs Fut. 10, 103, (1985)

46. S.R. Burzynski, Adv. Exp. C h. Chemother. 6, $45,(1988)$

47. D.C.Bienko, D. Michalska, S.Roszak, W. Wojciechowski, J.Phys.Chem. A101, 7834-7841,(1997)

48. W.B.Taylor, Biometrics 13, 1-12,(1957).

49. S. Joshi, N. Khosla, Indian drugs ,31, 548-550,(1994).

50. N. Siddiqui, S. N. Pandeya, S. A. Khan, J. Stable, A. Ran, M. Alam, Md. Arshad, M. A. Bhat, Bioorg. Med. Chem. Letters, 17,255-259,(2007).

51. S. Joshi, N. Khosla, D. Khare, P.Tiwari, Acta Pharm., 52,197-206,(2002).

52. S. Joshi, N. Khosla, P. Tiwari, Bioorg. Med. Chem., 12,571-576,(2002).

53. ACD-Lab software for calculating the referred Physicochemical ParametersChem Sketch 3.0,www.acdlabs.com

54. H.Wiener, J. Am. Chem .Soc., 69.17,(1947).

55. L. B. Kier, L.H. Hall, Molecular Connectivity in Chemistry and Drug Research, Academic: New York, (1976).

56. M.V. Diudea, M.S. Florescu, P.V. Khadikar, Molecular Topology and Its Applications, EFICON, Bucharest, 412 ,(2006).

57. M. Randic, J. Am.Chem. Soc, 97,6609,(1975).

58. The DRAGON Plus v 55 program is available from Todeschini, $\mathrm{R}$ Talete srl, via Pisani, 13-20124 Milano, Italy

59. HyperChem Software, Hypercube Inc Florida Science and Technology Park ,1115 NW $4^{\text {th }}$ street Gainesvilla Florida ,326001, USA (2006).

60. S.Chaterjee, A.S.Hadi, B.Price, Regression Analysis by Examples, $3^{\text {rd }} \mathrm{Ed}$ Wiley: New York, (2000).

61. M. S. Tute, History and Objectives of Quantitative Drug Design in Advances in Drug Research, N. J. Harter, A. B. Simmord, (Eds), Academic Press: London 6, 1, (1971)

62. S. Joshi, A. D. Manikpuri, D. Khare, P. V. Khadikar, Oxid. Commun. 33, (2010) (i) B.subtilis

(i) Using variables: C2, C9-C13. (ii) Using variables : C2,C14-C31. (iii)Using variables : $\mathrm{C} 2, \mathrm{C} 9-\mathrm{C} 31$.

\begin{tabular}{|c|c|c|}
\hline $\begin{array}{l}\text { Model } \\
\text { Size }\end{array}$ & $\mathbf{R}^{2}$ & $\begin{array}{l}\text { Coded } \\
\text { Variables }\end{array}$ \\
\hline 1 & 0.1718 & A \\
\hline 2 & 0.1722 & $\mathrm{AC}$ \\
\hline 3 & 0.2495 & BDF \\
\hline 4 & 0.2535 & BDEF \\
\hline 5 & 0.2595 & ABDEF \\
\hline 6 & 0.2611 & ABCDEF \\
\hline $\begin{array}{l}\text { Model } \\
\text { Size }\end{array}$ & $\mathbf{R}^{2}$ & $\begin{array}{l}\text { Coded } \\
\text { Variables }\end{array}$ \\
\hline 1 & 0.0630 & A \\
\hline 2 & 0.1113 & $\mathrm{AR}$ \\
\hline 3 & 0.2379 & FIR \\
\hline 4 & 0.2727 & FIPR \\
\hline 5 & 0.2929 & FIJPR \\
\hline 6 & 0.3062 & DFIJPR \\
\hline 7 & 0.3189 & DFILPQR \\
\hline 8 & 0.3277 & DFILOPQR \\
\hline 9 & 0.3576 & DEHIJLOQR \\
\hline 10 & 0.3863 & DEHIJLOPQR \\
\hline $\begin{array}{l}\text { Model } \\
\text { Size }\end{array}$ & $\mathbf{R}^{2}$ & \begin{tabular}{|l|} 
Coded \\
Variables \\
\end{tabular} \\
\hline 1 & 0.0693 & $\mathrm{~B}$ \\
\hline 2 & 0.0993 & $\mathrm{BJ}$ \\
\hline 3 & 0.1812 & BJW \\
\hline 4 & 0.2136 & ABJW \\
\hline 5 & 0.2241 & ABJUW \\
\hline 6 & 0.2433 & AJMQUW \\
\hline 7 & 0.2623 & ABJMUVW \\
\hline 8 & 0.2748 & ABJMQTUW \\
\hline 9 & 0.2876 & ABJMQTUVW \\
\hline 10 & 0.2896 & ABJMQSTUVW \\
\hline
\end{tabular}

(ii) S.typhi

(i) Using variables: C2, C9-C13(ii) Using variables: C2, C14-C31. (iii) Using variables: $\mathrm{C} 2, \mathrm{C} 9-\mathrm{C} 31$.

\begin{tabular}{|l|l|l|}
\hline $\begin{array}{l}\text { Model } \\
\text { Size }\end{array}$ & $\mathbf{R}^{2}$ & $\begin{array}{l}\text { Coded } \\
\text { Variables }\end{array}$ \\
\hline 1 & 0.2866 & C \\
\hline 2 & 0.4293 & EF \\
\hline 3 & 0.4508 & AEF \\
\hline 4 & 0.4549 & ABEF \\
\hline 5 & 0.4592 & ABDEF \\
\hline 6 & 0.4592 & ABCDEF \\
\hline $\begin{array}{l}\text { Model } \\
\text { Size }\end{array}$ & $\mathbf{R}^{2}$ & $\begin{array}{l}\text { Coded } \\
\text { Variables }\end{array}$ \\
\hline 1 & 0.3687 & I \\
\hline 2 & 0.5385 & IN \\
\hline 3 & 0.6190 & INU \\
\hline 4 & 0.6797 & AINX \\
\hline 5 & 0.7241 & AFINU \\
\hline 6 & 0.7823 & INRSTU \\
\hline 7 & 0.8114 & AINRSTU \\
\hline 8 & 0.8328 & AINQRSTU \\
\hline 9 & 0.8493 & AINQRSTUX \\
\hline 10 & 0.8584 & ABINQRSTUX \\
\hline
\end{tabular}




\begin{tabular}{|l|l|l|}
\hline $\begin{array}{l}\text { Model } \\
\text { Size }\end{array}$ & $\mathbf{R}^{2}$ & $\begin{array}{l}\text { Coded } \\
\text { Variables }\end{array}$ \\
\hline 1 & 0.3687 & D \\
\hline 2 & 0.5385 & DI \\
\hline 3 & 0.6190 & DIP \\
\hline 4 & 0.6797 & ADIS \\
\hline 5 & 0.7140 & ADIPS \\
\hline 6 & 0.7646 & DIOPRS \\
\hline 7 & 0.8110 & DIMOPRS \\
\hline 8 & 0.8255 & ADIMOPRS \\
\hline 9 & 0.8493 & ADILMNOPS \\
\hline 10 & 0.8580 & ADFILMNOPS \\
\hline
\end{tabular}

(3) E.coli

(i)Using variables: C2, C9-C13. (ii) Using variables: C2, C14-C31. (iii)Using variables: $\mathrm{C} 2, \mathrm{C} 9-\mathrm{C} 31$.

\begin{tabular}{|c|c|c|}
\hline $\begin{array}{l}\text { Model } \\
\text { Size }\end{array}$ & $\mathbf{R}^{2}$ & $\begin{array}{l}\text { Coded } \\
\text { Variables }\end{array}$ \\
\hline 1 & 0.0790 & $\mathrm{C}$ \\
\hline 2 & 0.3151 & $\mathrm{EF}$ \\
\hline 4 & 0.3378 & $\mathrm{ABEF}$ \\
\hline 3 & 0.3328 & AEF \\
\hline 5 & 0.3400 & ABCEF \\
\hline 6 & 0.3400 & ABCDEF \\
\hline $\begin{array}{l}\text { Model } \\
\text { Size }\end{array}$ & $\mathbf{R}^{2}$ & \begin{tabular}{|l|l} 
Coded \\
Variables
\end{tabular} \\
\hline 1 & 0.2784 & $\mathrm{U}$ \\
\hline 2 & 0.4101 & $\mathrm{AM}$ \\
\hline 3 & 0.5224 & AMW \\
\hline 4 & 0.5922 & AMUW \\
\hline 5 & 0.6099 & AJMUV \\
\hline 6 & 0.6294 & ABJMUV \\
\hline 7 & 0.7714 & ABDEKUV \\
\hline 8 & 0.7836 & ABDEHKUV \\
\hline 9 & 0.7993 & ABDEGKRUW \\
\hline 10 & 0.8047 & ABCDEHKRUW \\
\hline $\begin{array}{l}\text { Model } \\
\text { Size }\end{array}$ & $\mathbf{R}^{2}$ & $\begin{array}{l}\text { Coded } \\
\text { Variables }\end{array}$ \\
\hline 1 & 0.2784 & $\mathrm{P}$ \\
\hline 2 & 0.4101 & $\mathrm{AH}$ \\
\hline 3 & 0.5224 & AHR \\
\hline 4 & 0.5922 & AHPR \\
\hline 5 & 0.6099 & AEHPQ \\
\hline 6 & 0.6197 & AEHPRS \\
\hline 7 & 0.7214 & ADEGHJQ \\
\hline 8 & 0.7577 & ACDEGHJQ \\
\hline 9 & 0.7877 & ACDEGHJOQ \\
\hline 10 & 0.8675 & BCDEGHJLOQ \\
\hline
\end{tabular}

(4)S.aureus

(i)Using variables: C2, C9-C13. (ii) Using variables: C2, C14-C31. (iii)Using variables: $\mathrm{C} 2, \mathrm{C} 9-\mathrm{C} 31$.

\begin{tabular}{|l|l|l|}
\hline $\begin{array}{l}\text { Model } \\
\text { Size }\end{array}$ & $\mathbf{R}^{2}$ & $\begin{array}{l}\text { Coded } \\
\text { Variables }\end{array}$ \\
\hline 1 & 0.2691 & G \\
\hline 2 & 0.3229 & GN \\
\hline 3 & 0.4946 & DKP \\
\hline 4 & 0.5242 & DKPQ \\
\hline 5 & 0.6138 & ADFGP \\
\hline 6 & 0.6514 & ADFGPQ \\
\hline
\end{tabular}

\begin{tabular}{|c|c|c|}
\hline 7 & 0.7389 & ABDGJPS \\
\hline 8 & 0.7763 & ABCDGJPS \\
\hline 9 & 0.8240 & ABCDEHJPS \\
\hline 10 & 0.8701 & ABCDEFHJPS \\
\hline $\begin{array}{l}\text { Model } \\
\text { Size }\end{array}$ & $\mathbf{R}^{2}$ & $\begin{array}{l}\text { Coded } \\
\text { Variables } \\
\end{array}$ \\
\hline 1 & 0.1118 & $\mathrm{~F}$ \\
\hline 2 & 0.3602 & $\mathrm{EF}$ \\
\hline 3 & 0.4866 & AEF \\
\hline 4 & 0.5640 & ADEF \\
\hline 5 & 0.5719 & ABDEF \\
\hline 6 & 0.5733 & ABCDEF \\
\hline
\end{tabular}

\begin{tabular}{|l|l|l|}
\hline $\begin{array}{l}\text { Model } \\
\text { Size }\end{array}$ & $\mathbf{R}^{2}$ & $\begin{array}{l}\text { Coded } \\
\text { Variables }\end{array}$ \\
\hline 1 & 0.2691 & L \\
\hline 2 & 0.3229 & LS \\
\hline 3 & 0.4946 & IPU \\
\hline 4 & 0.5242 & IPUV \\
\hline 5 & 0.5737 & DIOPU \\
\hline 6 & 0.6869 & AIJMOU \\
\hline 7 & 0.7707 & AIJMOUX \\
\hline 8 & 0.7898 & AIJMOQUX \\
\hline 9 & 0.8118 & ACIJMOQUX \\
\hline 10 & 0.8335 & ACIJMOQRUX \\
\hline
\end{tabular}

(5) K.pneumoniae

(i)Using variables: $\mathrm{C} 2, \mathrm{C} 9-\mathrm{C} 13$ (ii) Using variables: $\mathrm{C} 2, \mathrm{C} 14-\mathrm{C} 31$ (iii) Using variables: $\mathrm{C} 2, \mathrm{C} 9-\mathrm{C} 31$.

\begin{tabular}{|c|c|c|}
\hline $\begin{array}{l}\text { Model } \\
\text { Size }\end{array}$ & $\mathbf{R}^{2}$ & $\begin{array}{l}\text { Coded } \\
\text { Variables }\end{array}$ \\
\hline 1 & 0.0058 & $\mathrm{~F}$ \\
\hline 2 & 0.0184 & $\mathrm{BF}$ \\
\hline 3 & 0.0474 & $\mathrm{BCF}$ \\
\hline 4 & 0.0567 & $\mathrm{BCEF}$ \\
\hline 5 & 0.0597 & ABCEF \\
\hline 6 & 0.0631 & ABCDEF \\
\hline $\begin{array}{l}\text { Model } \\
\text { Size }\end{array}$ & $\mathbf{R}^{2}$ & $\begin{array}{l}\text { Coded } \\
\text { Variables }\end{array}$ \\
\hline 1 & 0.0807 & $\mathrm{P}$ \\
\hline 2 & 0.1521 & DP \\
\hline 3 & 0.3034 & DEP \\
\hline 4 & 0.4448 & GHJL \\
\hline 5 & 0.4753 & GHJLP \\
\hline 6 & 0.4851 & GHJLOP \\
\hline 7 & 0.5093 & FGHJLNP \\
\hline 8 & 0.6532 & BCEGHJOQ \\
\hline 9 & 0.7020 & BCEGHJOQR \\
\hline 10 & 0.7271 & BCEGHJNOQR \\
\hline $\begin{array}{l}\text { Model } \\
\text { Size }\end{array}$ & $\mathbf{R}^{2}$ & $\begin{array}{l}\text { Coded } \\
\text { Variables }\end{array}$ \\
\hline 1 & 0.0807 & $\mathrm{U}$ \\
\hline 2 & 0.1603 & $\mathrm{CU}$ \\
\hline 3 & 0.3181 & $\mathrm{CJU}$ \\
\hline 4 & 0.3884 & CJMU \\
\hline 5 & 0.4576 & CJMQU \\
\hline 6 & 0.5170 & CDEJMU \\
\hline 7 & 0.5723 & ACDEJMU \\
\hline 8 & 0.6142 & ACDEJMQU \\
\hline 9 & 0.7483 & CDGHLMTVX \\
\hline 10 & 0.7604 & CFGHLMTVWX \\
\hline
\end{tabular}


(6) P.aeruginosa

(i)Using variables: $\mathrm{C} 2, \mathrm{C} 9-\mathrm{C} 13$. (ii) Using variables: $\mathrm{C} 2, \mathrm{C} 14-\mathrm{C} 31$ (iii)Using variables: C2, C9-C31.

\begin{tabular}{|l|l|l|}
\hline $\begin{array}{l}\text { Model } \\
\text { Size }\end{array}$ & $\mathbf{R}^{2}$ & $\begin{array}{l}\text { Coded } \\
\text { Variables }\end{array}$ \\
\hline 1 & 0.1143 & B \\
\hline 2 & 0.1830 & BV \\
\hline 3 & 0.2670 & BJV \\
\hline 4 & 0.3463 & FMNV \\
\hline 5 & 0.3899 & EMNUW \\
\hline 6 & 0.4040 & EJNRUV \\
\hline 7 & 0.4633 & CIKNRUW \\
\hline 8 & 0.4846 & IKNRSTUX \\
\hline 9 & 0.5220 & CIKNRSTUX \\
\hline 10 & 0.5293 & CFIKNRSTU \\
\hline
\end{tabular}

\begin{tabular}{|l|l|l|}
\hline $\begin{array}{l}\text { Model } \\
\text { Size }\end{array}$ & $\mathbf{R}^{2}$ & $\begin{array}{l}\text { Coded } \\
\text { Variables }\end{array}$ \\
\hline 1 & 0.1758 & E \\
\hline 2 & 0.2032 & AF \\
\hline 3 & 0.2085 & ACD \\
\hline 4 & 0.2144 & ACDE \\
\hline 5 & 0.2181 & ACDEF \\
\hline 6 & 0.2192 & ABCDEF \\
\hline $\begin{array}{l}\text { Model } \\
\text { Size }\end{array}$ & $\mathbf{R}^{2}$ & $\begin{array}{l}\text { Coded } \\
\text { Variables }\end{array}$ \\
\hline 1 & 0.1031 & Q \\
\hline 2 & 0.1227 & QS \\
\hline 3 & 0.1395 & AQS \\
\hline 4 & 0.3097 & DFIM \\
\hline 5 & 0.3603 & DFIMQ \\
\hline 6 & 0.4273 & DFIMPR \\
\hline 7 & 0.4579 & DFIMNPR \\
\hline 8 & 0.4846 & DFIMNOPS \\
\hline 9 & 0.4978 & CDFIMNOPS \\
\hline 10 & 0.5124 & CDHIJMNOPS \\
\hline
\end{tabular}

(2). Correlation matrix for the parameters of most appropriate model for modeling antibacterial activity.

B.subtilis

\begin{tabular}{|c|c|c|c|c|c|c|c|c|c|}
\hline & $\mathbf{C 2}$ & $\mathbf{C 3}$ & $\mathbf{C 1 7}$ & $\mathbf{C 2 0}$ & $\mathbf{C 2 4}$ & $\mathbf{C 2 7}$ & $\mathbf{C 2 8}$ & $\mathbf{C 3 0}$ & $\mathbf{C 3 2}$ \\
\hline $\mathbf{C 2}$ & 1.0000 & 0.4219 & 0.4146 & 0.4270 & 0.3689 & -0.0481 & -0.1762 & -0.1112 & 0.2509 \\
\hline $\mathbf{C 3}$ & 0.4219 & 1.0000 & 0.9726 & 0.9745 & 0.9061 & 0.5369 & 0.2669 & 0.4923 & 0.1334 \\
\hline $\mathbf{C 1 7}$ & 0.4146 & 0.9726 & 1.0000 & 0.9988 & 0.9153 & 0.4974 & 0.2964 & 0.4745 & 0.0777 \\
\hline $\mathbf{C 2 0}$ & 0.4270 & 0.9745 & 0.9988 & 1.0000 & 0.9111 & 0.5021 & 0.2772 & 0.4702 & 0.0918 \\
\hline $\mathbf{C 2 4}$ & 0.3689 & 0.9061 & 0.9153 & 0.9111 & 1.00001 & 0.4814 & 0.2737 & $0.444^{\prime} 0$ & 0.1228 \\
\hline $\mathbf{C 2 7}$ & -0.0481 & 0.5369 & 0.4974 & 0.5021 & 0.4814 & 1.0000 & 0.2610 & 0.8064 & 0.1670 \\
\hline $\mathbf{C 2 8}$ & -0.1762 & 0.2669 & 0.2964 & 0.2772 & 0.2737 & 0.2610 & 1.0000 & 0.1793 & -0.0432 \\
\hline $\mathbf{C 3 0}$ & -0.1112 & 0.4923 & 0.4745 & 0.4702 & 0.4410 & 0.8064 & 0.1793 & 1.0000 & 0.1906 \\
\hline $\mathbf{C 3 2}$ & 0.2509 & 0.1334 & 0.0777 & 0.0918 & 0.1228 & 0.1670 & -0.0432 & 0.1906 & 1.0000 \\
\hline
\end{tabular}

S.typhi

\begin{tabular}{|c|c|c|c|c|c|c|c|c|c|}
\hline & $\mathbf{C 2}$ & $\mathbf{C 1 6}$ & $\mathbf{C 2 1}$ & $\mathbf{C 2 4}$ & $\mathbf{C 2 5}$ & $\mathbf{C 2 6}$ & $\mathbf{C 2 7}$ & $\mathbf{C 2 8}$ & $\mathbf{C 3 3}$ \\
\hline $\mathbf{C 2}$ & 1.0000 & 0.3080 & 0.3315 & 0.3688 & 0.3297 & 0.2483 & -0.0481 & -0.1762 & -0.1436 \\
\hline $\mathbf{C 1 6}$ & 0.3080 & 1.0000 & 0.9937 & 0.8849 & 0.9807 & 0.6253 & 0.5789 & 0.3521 & 0.6072 \\
\hline $\mathbf{C 2 1}$ & 0.3315 & 0.9937 & 1.0000 & 0.9011 & 0.9943 & 0.6212 & 0.5378 & 0.3518 & 0.5575 \\
\hline $\mathbf{C 2 4}$ & 0.3688 & 0.8849 & 0.9011 & 1.0000 & 0.9023 & 0.4646 & 0.4813 & 0.2736 & 0.5252 \\
\hline $\mathbf{C 2 5}$ & 0.3297 & 0.9807 & 0.9943 & 0.9023 & 1.0000 & 0.6412 & 0.5009 & 0.3536 & 0.5323 \\
\hline $\mathbf{C 2 6}$ & 0.2483 & 0.6253 & 0.6212 & 0.4646 & 0.6412 & 1.0000 & 0.1160 & 0.1982 & 0.2289 \\
\hline $\mathbf{C 2 7}$ & -0.0481 & 0.5789 & 0.5378 & 0.4813 & 0.5009 & 0.1160 & 1.0000 & 0.2609 & 0.3838 \\
\hline $\mathbf{C 2 8}$ & -0.1762 & 0.3521 & 0.3518 & 0.2736 & 0.3536 & 0.1982 & 0.2609 & 1.0000 & 0.4722 \\
\hline $\mathbf{C 3 3}$ & -0.1436 & 0.6072 & 0.5575 & 0.5252 & 0.5323 & 0.2289 & 0.3838 & 0.4722 & 1.0000 \\
\hline
\end{tabular}


E.coli

\begin{tabular}{|l|c|c|c|c|c|c|c|c|c|}
\hline & C2 & C9 & C11 & C12 & C15 & C18 & C28 & C29 & C34 \\
\hline C2 & 1.0000 & 0.6249 & 0.4232 & 0.4233 & 0.3286 & 0.4322 & -0.1762 & -0.1071 & -0.4132 \\
\hline C9 & 0.6249 & 1.0000 & 0.7893 & 0.7895 & 0.6337 & 0.7448 & -0.0007 & 0.1882 & -0.0267 \\
\hline C11 & 0.4232 & 0.7893 & 1.0000 & 1.0000 & 0.9628 & 0.9900 & 0.2663 & 0.4913 & 0.2523 \\
\hline C12 & 0.4233 & 0.7895 & 1.0000 & 1.0000 & 0.9627 & 0.9899 & 0.2662 & 0.4911 & 0.2523 \\
\hline C15 & 0.3286 & 0.6337 & 0.9628 & 0.9627 & 1.0000 & 0.9791 & 0.3389 & 0.5314 & 0.2559 \\
\hline C18 & 0.4322 & 0.7448 & 0.9900 & 0.9899 & 0.9791 & 1.0000 & 0.2765 & 0.4800 & 0.2080 \\
\hline C28 & -0.1761 & -0.0006 & 0.2663 & 0.2662 & 0.3389 & 0.2765 & 1.0000 & 0.1830 & 0.5276 \\
\hline C29 & -0.1071 & 0.1882 & 0.4913 & 0.4911 & 0.5314 & 0.4800 & 0.1830 & 1.0000 & 0.0675 \\
\hline C34 & -0.4132 & -0.0267 & 0.2523 & 0.2523 & 0.2559 & 0.2080 & 0.9791 & 1.0000 & 0.9791 \\
\hline
\end{tabular}

S.aureus

\begin{tabular}{|c|c|c|c|c|c|c|c|c|c|}
\hline & $\mathbf{C 2}$ & $\mathbf{C 1 6}$ & $\mathbf{C 1 7}$ & $\mathbf{C 2 0}$ & $\mathbf{C 2 2}$ & $\mathbf{C 2 4}$ & $\mathbf{C 2 8}$ & $\mathbf{C 3 1}$ & $\mathbf{C 3 5}$ \\
\hline $\mathbf{C 2}$ & 1.0000 & 0.3080 & 0.4145 & 0.4269 & 0.4237 & 0.3688 & -0.1762 & -0.0529 & 0.1437 \\
\hline $\mathbf{C 1 6}$ & 0.3080 & 1.0000 & 0.9520 & 0.9467 & 0.9796 & 0.8849 & 0.3521 & 0.3764 & 0.3216 \\
\hline $\mathbf{C 1 7}$ & 0.4145 & 0.9520 & 1.0000 & 0.9987 & 0.9729 & 0.9153 & 0.2963 & 0.2350 & 0.2868 \\
\hline $\mathbf{C 2 0}$ & 0.4269 & 0.9467 & 0.9987 & 1.0000 & 0.9745 & 0.9110 & 0.2772 & 0.2215 & 0.2912 \\
\hline $\mathbf{C 2 2}$ & 0.4237 & 0.9796 & 0.9729 & 0.9745 & 1.0000 & 0.8961 & 0.2782 & 0.2603 & 0.2652 \\
\hline $\mathbf{C 2 4}$ & 0.3688 & 0.8849 & 0.9153 & 0.9110 & 0.8961 & 1.0000 & 0.2736 & 0.1839 & 0.2162 \\
\hline $\mathbf{C 2 8}$ & -0.1761 & 0.3521 & 0.2963 & 0.2772 & 0.2782 & 0.2736 & 1.0000 & 0.0927 & -0.1530 \\
\hline $\mathbf{C 3 1}$ & -0.0529 & 0.3764 & 0.2350 & 0.2215 & 0.2603 & 0.1839 & 0.0927 & 1.0000 & 0.3186 \\
\hline $\mathbf{C 3 5}$ & 0.1430 & 0.3216 & 0.2868 & 0.2912 & 0.2652 & 0.2162 & -0.1530 & 0.3182 & 1.0000 \\
\hline
\end{tabular}

K.pneumoniae

\begin{tabular}{|c|c|c|c|c|c|c|c|c|c|}
\hline & C2 & C10 & C11 & C12 & C17 & C20 & C24 & C28 & C36 \\
\hline C2 & 1.0000 & 0.2764 & 0.4232 & 0.4233 & 0.4145 & 0.4269 & 0.3688 & -0.1762 & 0.1127 \\
\hline C10 & 0.2768 & 1.0000 & 0.9609 & 0.9608 & 0.9426 & 0.9346 & 0.8934 & 0.3878 & 0.1498 \\
\hline C11 & 0.4232 & 0.9609 & 1.0000 & 1.0000 & 0.9727 & 0.9746 & 0.9063 & 0.2663 & 0.1297 \\
\hline C12 & 0.4233 & 0.9608 & 1.0000 & 1.0000 & 0.9727 & 0.9746 & 0.9063 & 0.2662 & 0.1297 \\
\hline C17 & 0.4145 & 0.9426 & 0.9727 & 0.9727 & 1.0000 & 0.9987 & 0.9153 & 0.2963 & 0.0399 \\
\hline C20 & 0.4269 & 0.9346 & 0.9746 & 0.9746 & 0.9987 & 1.0000 & 0.9110 & 0.2772 & 0.0504 \\
\hline C24 & 0.3688 & 0.8934 & 0.9063 & 0.9063 & 0.9153 & 0.9110 & 1.0000 & 0.2736 & 0.1732 \\
\hline C28 & -0.1761 & 0.3878 & 0.2663 & 0.2662 & 0.2963 & 0.2772 & 0.2736 & 1.0000 & -0.2846 \\
\hline C36 & 0.1124 & 0.1498 & 0.1297 & 0.1297 & 0.0399 & 0.0504 & 0.1732 & -0.2846 & 1.0000 \\
\hline
\end{tabular}

\section{P.aeruginosa}

\begin{tabular}{|l|c|c|c|c|c|c|c|c|c|}
\hline & $\mathbf{C 1 6}$ & $\mathbf{C 1 8}$ & $\mathbf{C 2 1}$ & $\mathbf{C 2 5}$ & $\mathbf{C 2 6}$ & $\mathbf{C 2 7}$ & $\mathbf{C 2 8}$ & $\mathbf{C 3 1}$ & $\mathbf{C 3 7}$ \\
\hline $\mathbf{C 1 6}$ & 1.0000 & 0.9818 & 0.9937 & 0.9807 & 0.6253 & 0.5789 & 0.3521 & 0.3764 & 0.2268 \\
\hline $\mathbf{C 1 8}$ & 0.9818 & 1.0000 & 0.9875 & 0.9768 & 0.5828 & 0.5147 & 0.2765 & 0.2871 & 0.2197 \\
\hline $\mathbf{C 2 1}$ & 0.9937 & 0.9875 & 1.0000 & 0.9943 & 0.6212 & 0.5378 & 0.3518 & 0.3461 & 0.1836 \\
\hline $\mathbf{C 2 5}$ & 0.9807 & 0.9768 & 0.9943 & 1.0000 & 0.6412 & 0.5009 & 0.3536 & 0.3479 & 0.1675 \\
\hline $\mathbf{C 2 6}$ & 0.6253 & 0.5828 & 0.6212 & 0.6412 & 1.0000 & 0.1160 & 0.1982 & 0.7700 & 0.0159 \\
\hline $\mathbf{C 2 7}$ & 0.5789 & 0.5147 & 0.5378 & 0.5009 & 0.1160 & 1.0000 & 0.2609 & 0.3795 & 0.3184 \\
\hline $\mathbf{C 2 8}$ & 0.3521 & 0.2765 & 0.3518 & 0.3536 & 0.1982 & 0.2609 & 1.0000 & 0.0927 & 0.1042 \\
\hline $\mathbf{C 3 1}$ & 0.3764 & 0.2871 & 0.3461 & 0.3479 & 0.7700 & 0.3795 & 0.0927 & 1.0000 & 0.1169 \\
\hline $\mathbf{C 3 7}$ & 0.2268 & 0.2197 & 0.1836 & 0.1675 & 0.0159 & 0.3184 & 0.1042 & 0.1169 & 1.0000 \\
\hline
\end{tabular}


J. Chil. Chem. Soc., 55, № 3 (2010)

(3) Ridge regression parameters: VIF, Tolerance, Eigen values, Condition number for the most appropriate model for modeling antibacterial activity.

\section{B.subtilis S.typhi}

\begin{tabular}{|l|l|l|l|l|}
\hline Variable & VIF & Tolerance & Eigenvalue & $\begin{array}{l}\text { Condition } \\
\text { Number }\end{array}$ \\
\hline C2 & 1.3667 & 0.6783 & 4.806702 & 1.00 \\
\hline C16 & 24.7792 & 0.0048 & 1.288230 & 3.73 \\
\hline C21 & 19.6221 & 0.0016 & 0.831546 & 5.78 \\
\hline C24 & 5.7580 & 0.1558 & 0.588309 & 8.17 \\
\hline C25 & 25.3768 & 0.0050 & 0.361899 & 13.28 \\
\hline C26 & 2.0528 & 0.3649 & 0.108315 & 44.38 \\
\hline C27 & 1.9469 & 0.4307 & 0.013966 & 344.16 \\
\hline
\end{tabular}

\begin{tabular}{|l|l|l|l|l|}
\hline Variable & VIF & Tolerance & Eigenvalue & $\begin{array}{l}\text { Condition } \\
\text { Number }\end{array}$ \\
\hline C2 & 1.6190 & 0.5921 & 4.758598 & 1.00 \\
\hline C3 & 16.5952 & 0.0446 & 1.540658 & 3.09 \\
\hline C17 & 16.0823 & 0.0015 & 0.930304 & 5.12 \\
\hline C20 & 15.8720 & 0.0015 & 0.432212 & 11.01 \\
\hline C24 & 5.7972 & 0.1464 & 0.185510 & 25.65 \\
\hline C27 & 3.0755 & 0.2633 & 0.119560 & 39.80 \\
\hline C24 & 10.2254 & 0.0701 & 0.002257 & 3148.50 \\
\hline C25 & 17.6452 & 0.0366 & 0.000001 & 6525191.27 \\
\hline
\end{tabular}

K.pneumoniae P.aeruginosa

\begin{tabular}{|l|l|l|l|l|}
\hline Variable & VIF & Tolerance & Eigenvalue & $\begin{array}{l}\text { Condition } \\
\text { Number }\end{array}$ \\
\hline C16 & 31.4770 & 0.0048 & 5.073812 & 1.00 \\
\hline C18 & 29.4035 & 0.0127 & 1.206077 & 4.21 \\
\hline C21 & 19.4545 & 0.0012 & 0.859504 & 5.90 \\
\hline C25 & 24.2164 & 0.0046 & 0.788952 & 6.43 \\
\hline C26 & 9.4800 & 0.0727 & 0.043209 & 117.42 \\
\hline C27 & 4.1585 & 0.1756 & 0.018254 & 277.95 \\
\hline C28 & 1.3646 & 0.5851 & 0.009341 & 543.20 \\
\hline
\end{tabular}

\begin{tabular}{|l|l|l|l|l|}
\hline Variable & VIF & Tolerance & Eigenvalue & $\begin{array}{l}\text { Condition } \\
\text { Number }\end{array}$ \\
\hline C2 & 1.5844 & 0.5515 & 6.019250 & 1.00 \\
\hline C10 & 16.2188 & 0.0165 & 1.196181 & 5.03 \\
\hline C11 & 7.0243 & 0.0000 & 0.552880 & 10.89 \\
\hline C12 & 7.0662 & 0.0000 & 0.134921 & 44.61 \\
\hline C17 & 13.4693 & 0.0010 & 0.069433 & 86.69 \\
\hline C20 & 12.6196 & 0.0010 & 0.026828 & 224.36 \\
\hline C24 & 6.0028 & 0.1428 & 0.000506 & 11896.45 \\
\hline C28 & 1.3852 & 0.6056 & 0.000000 & 94674753.04 \\
\hline
\end{tabular}

\section{E.coli S.aureus}

\begin{tabular}{|l|l|l|l|l|}
\hline Variable & VIF & Tolerance & Eigenvalue & $\begin{array}{l}\text { Condition } \\
\text { Number }\end{array}$ \\
\hline C2 & 1.5640 & 0.4156 & 5.131911 & 1.00 \\
\hline C16 & 25.2418 & 0.0063 & 1.242010 & 4.13 \\
\hline C17 & 14.0883 & 0.0009 & 0.923066 & 5.56 \\
\hline C20 & 11.8939 & 0.0008 & 0.510967 & 10.04 \\
\hline C22 & 28.7419 & 0.0049 & 0.131963 & 38.89 \\
\hline C24 & 5.8384 & 0.1495 & 0.053840 & 95.32 \\
\hline C28 & 1.3123 & 0.6546 & 0.005835 & 879.56 \\
\hline
\end{tabular}

\begin{tabular}{|l|l|l|l|l|}
\hline Variable & VIF & Tolerance & Eigenvalue & $\begin{array}{l}\text { Condition } \\
\text { Number }\end{array}$ \\
\hline C2 & 1.9409 & 0.4508 & 5.092069 & 1.00 \\
\hline C9 & 5.7861 & 0.1059 & 1.466185 & 3.47 \\
\hline C11 & 11.1715 & 0.0000 & 0.802052 & 6.35 \\
\hline C12 & 11.2217 & 0.0000 & 0.366760 & 13.88 \\
\hline C15 & 25.4340 & 0.0181 & 0.251692 & 20.23 \\
\hline C18 & 36.8436 & 0.0071 & 0.015330 & 332.15 \\
\hline C28 & 1.2886 & 0.7392 & 0.005911 & 861.46 \\
\hline C29 & 1.6359 & 0.5153 & 0.000000 & 91622650.97 \\
\hline
\end{tabular}

